\title{
Climatic risk zoning for corn and palisade grass (Brachiaria brizantha cv. Marandu) cultivated in integrated crop-livestock systems in São Paulo state, Brazil
}

\author{
Patrícia Menezes Santos ${ }^{1}$, José Ricardo Macedo Pezzopane ${ }^{1}$, Fernando Campos Mendonça ${ }^{1}$, \\ Giovana Maranhão Bettiol ${ }^{1}$, Balbino Antônio Evangelista ${ }^{2}$, Fernando Antônio Macena da Silva ${ }^{2}$ \\ ${ }^{1}$ Embrapa Pecuária Sudeste, São Carlos, SP. \\ 2 Embrapa Cerrados, Brasília, DF.
}

ABSTRACT - Climatic risk zoning allows the identification of areas of low risk of reduced crop productivity due to climatic events. In Brazil, losses to agriculture due to climate are mainly caused by drought. The objective of this research was to determine areas of low climatic risk for corn and palisade grass cultivated in integrated crop-livestock systems in Sao Paulo state. Corn varieties characterized by a 120-day growing cycle and soil with three different water holding capacities (sandy, medium and clayey soils) were considered. A daily water balance model was used to simulate planting dates between September and December. The water requirement satisfaction index (WRSI) was calculated for critical phenological phases of both cultures (germination, emergence and tillering of palisade grass and flowering and grain filling of corn). The WRSI values, calculated for a minimum frequency of $80 \%$, were located spatially using the SPRING v. 5.1 geographic information system and the most favorable periods for sowing in different areas were determined. The results showed that there are areas of low climatic risk for cultivation of corn and palisade grass in integrated crop-livestock production systems in Sao Paulo state. Although climatic risk in these areas also depends on soil type, the most favorable period for planting is between October and November.

Key Words: evapotranspiration, integrated crop-livestock production systems, rainfall, water balance

\section{Introduction}

Brazil has the largest commercial cattle herd of the world, and is the global leader in beef exports (ABIEC, 2010). The results of the Agricultural Census, conducted in 2006, indicate that pastures are present in over $50 \%$ of the country's rural establishments, occupying around 160 million hectares (IBGE, 2009).

Although grasses are perennial plants, there is still a need for frequent replanting of pastures, due to factors that degrade them and reduce their productivity (for example, overgrazing and inadequate soil management). Estimates made from data on grass seed sales indicate that roughly 10 million hectares of pasture are planted annually in Brazil.

Palisade grass (Brachiaria brizantha) is the most commonly planted forage grass in Brazil (Miles et al., 2004) and has been recommended for integrated crop-livestock systems, both through combined planting and crop rotation. According to the results of the 2006 Agricultural Census, about $5 \%$ of farms and ranches in the country use crop rotation for revitalization of pasture areas (IBGE, 2009).

The combined sowing of corn and palisade grass is a means of preventing degradation of pasture in integrated crop-livestock systems. In tests to assess the suitability of corn cultivars for joint planting with palisade grass, Oliveira et al. (1996) observed corn yields from 2,227 to $4,246 \mathrm{~kg} / \mathrm{ha}$. In an evaluation conducted 150 days after planting, Araújo (2011b) observed lower dry mass output of palisade grass in combination with corn (1,181 kg of DM/ha) than for palisade grass grown alone (5,722 kg DM/ha). In that experiment, the corn yield was approximately $10,000 \mathrm{~kg} / \mathrm{ha}$ (Araújo, 2011b).

The individual analyses of the two cultures show that unfavorable climate conditions limit the growth and development of the plants, particularly water deficiency (Guenni et al., 2002; Bergamaschi et al., 2006). For corn, the most critical periods are flowering and grain filling (Sans et al., 2001; Bergamaschi et al., 2004), while for palisade grass the germination, emergence and tillering phases are the most critical for establishment of productive pastures (Araujo et al., 2011a).

Climatic risk zoning is a technique that allows choosing the best time of the year and/or region to sow crops, based on knowledge of the variability of climate elements such as rainfall and reference evapotranspiration, aiming to select periods during which the prevailing climate 
conditions indicate sufficient water availability for the plants' most critical periods, thus helping to reduce exposure to climate risks (Andrade Junior et al., 2007; Pezzopane et al., 2010).

The objective of this study was to conduct climatic risk zoning for the joint planting of corn and palisade grass in the state of São Paulo, in order to indicate the most favorable period for establishment of these crops based on the risk of water deficiency, considering both rainfall and soil type.

\section{Material and Methods}

Identification of the most favorable periods for combined planting of corn and Brachiaria brizantha cv. Marandu in São Paulo state was based on the interaction of water availability, soil type and critical development periods, as these are the main factors that determine the success of integrated planting.

The water balance simulations for the joint corn-palisade grass cropping were performed with the aid of the Sarrazon computational program (Baron et al., 1996), considering sowing on the $5^{\text {th }}, 15^{\text {th }}$ and $25^{\text {th }}$ day of each month, in the period from September to December. For the simulations, historical series consisting of daily rainfall data going back from 15 to 30 years, obtained from measurement posts located in the state of São Paulo belonging to the National Water Agency (ANA) and the Department of Water and Electricity (DAEE) were used (Figure 1). The reference evapotranspiration (ETo) estimate was obtained by the Penman-Monteith method.

To estimate crop evapotranspiration (Etc), crop coefficient (Kc) values, necessary for quantification of the water demand of the combined crops, were obtained from Silva (2007) (Table 1).

An average corn growing cycle of 120 days was considered; a figure that is representative of a normal cultivation cycle in different regions of the state for the planting times used in this study (Brunini et al., 2001)

The water balance was calculated considering three soil types regarding available water capacity (AWC): soil type 1 = low water storage capacity ( $20 \mathrm{~mm}$ ), corresponding to quartz neosols and alluvial soils, with clay concentrations under $15 \%$; soil type 2 = medium water storage capacity (40 mm), corresponding to yellow and reddish-yellow latosols, with clay concentrations between 15 and $35 \%$; and soil type 3 = high water storage capacity (60 mm), corresponding to reddish-yellow and dark red podzols, purple cambisols and purple and dark red latosols, with over 35\% clay.
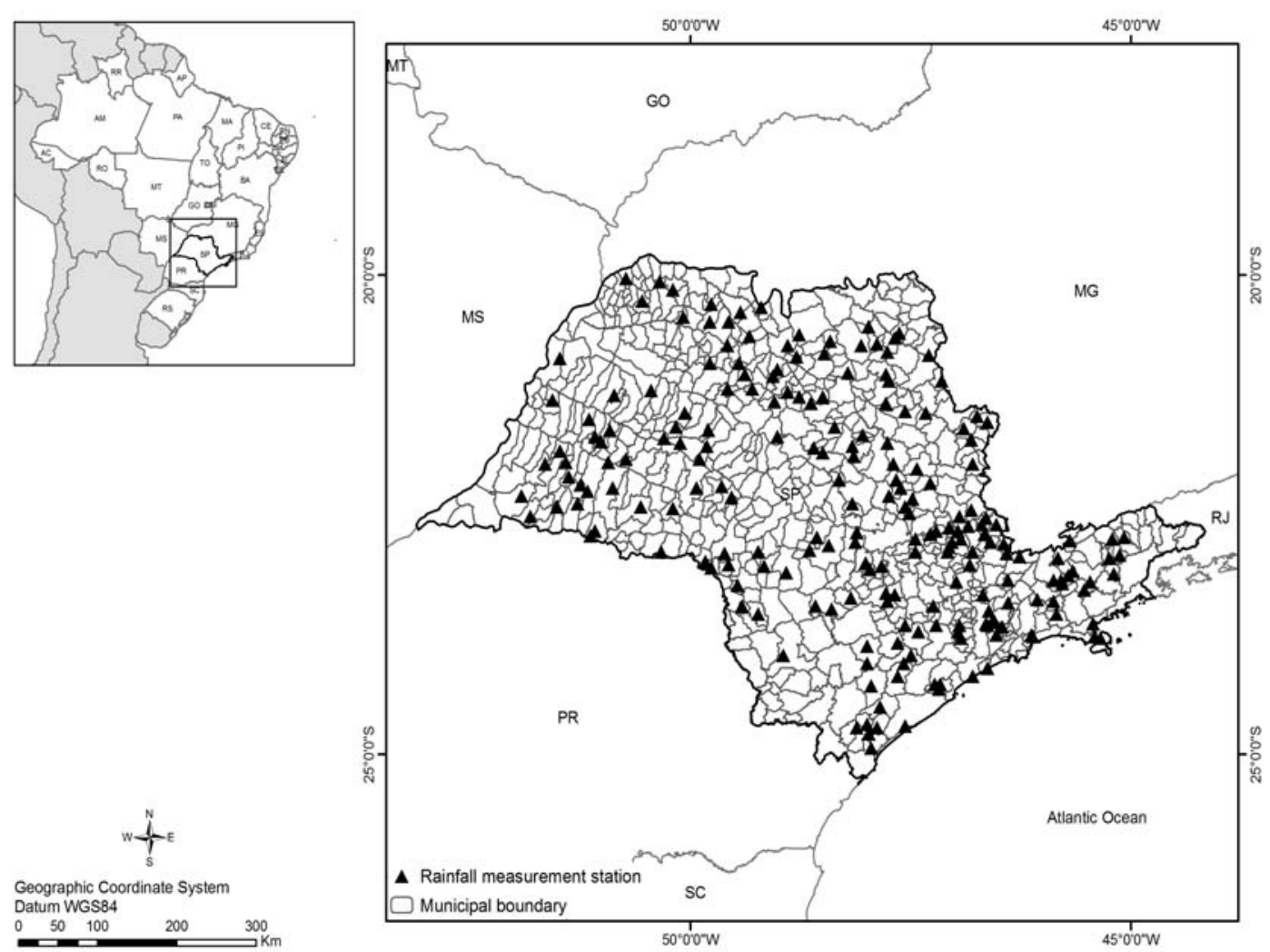

Figure 1 - Spatial distribution of the rainfall measurement stations in São Paulo state used in this study. 
Table 1 - Ten-day crop coefficient (Kc) for combined growing of corn and palisade grass in Brazilian savanna regions Ten-day period after planting

\begin{tabular}{|c|c|c|c|c|c|c|c|c|c|c|c|c|c|}
\hline & 1 & 2 & 3 & 4 & 5 & 6 & 7 & 8 & 9 & 10 & 11 & 12 & 13 \\
\hline
\end{tabular}

Source: Silva et al. (2007).

The water requirement satisfaction index (WRSI), defined as the ratio between real evapotranspiration (ETr) and maximum evapotranspiration (ETm), was used as a climatic risk indicator for the different combined planting periods. For this purpose, the WRSI was considered in two periods: (1) the phases of germination, emergence and tillering of the palisade grass, which are critical for establishment of pastures (Araujo, 20011a); and (2) the flowering and grain filling phases of corn, which are critical for yield and are strongly affected by water deficit (Brunini et al., 2001).

Three WRSI classes were defined for each crop to differentiate the locations within São Paulo state. In the case of palisade grass these areas were defined as having WRSI $>0.60$ (low risk); $0.60>$ WRSI $>0.50$ (medium risk); and WRSI $<0.50$ (high risk). The respective areas for corn were defined as WRSI $>0.55$ (low risk); $0.55>$ WRSI $>0.45$ (medium risk); and WRSI $<0.45$ (high risk). Both analyses included assessment of the WRSI frequency for $80 \%$ occurrence.

The WRSI values calculated to define the regions regarding climatic risk were spatialized with the SPRING computational program (INPE). After verification of the errors and the fit of the interpolation values, thematic maps were prepared to represent the best dates for combined sowing of corn and palisade grass in the state of São Paulo, to identify the regions with higher and lower risk of this integrated cropping system.

The climatic risk analysis for each joint planting date entailed assessment of the behavior of the WRSI in the two phases, to demarcate the regions based on the three risk levels for each phase (Table 2).

Table 2 - Definition of the climatic risk for joint growing of corn and palisade grass in the state of São Paulo based on the behavior of the water requirement satisfaction index (WRSI) for palisade grass (Phase 1) and corn (Phase 2)

\begin{tabular}{lclc}
\hline Phase $1^{\mathrm{a}}$ & & Phase $^{\mathrm{b}}$ & Result \\
\hline Low risk & $\times$ & Low Risk & Low risk \\
Low risk & $\times$ & Medium Risk & Medium risk \\
Low risk & $\times$ & High Risk & High risk \\
Medium risk & $\times$ & Low Risk & Medium risk \\
Medium risk & $\times$ & Medium Risk & Medium risk \\
Medium risk & $\times$ & High Risk & High risk \\
High risk & $\times$ & Low Risk & High risk \\
High risk & $\times$ & Medium Risk & High risk \\
High risk & $\times$ & High Risk & High risk \\
\hline
\end{tabular}

a Germination and emergence of palisade grass.

b Flowering and grain filling of corn.

\section{Results and Discussion}

The definition of the favorable sowing periods only considered the water availability criteria. Therefore, the indication of the favorable periods is related to the times of the year when there is a lower chance of losses caused by lack of water during the most critical phases for the two crops (Phases 1 and 2).

By considering the interaction between the periods of joint planting and soil types, 36 maps defining the areas and type of associated risk due to water deficiency for the state were prepared. Each map indicates, for a ten-day period in the months of September through December, the state regions with high, medium and low risk for each soil type, based on the spatial distribution of the WRSI values.

As an example, we present spatial distribution maps of the climate risks for joint planting of corn and palisade grass in the second ten-day period of each month $\left(11^{\text {th }}\right.$ through $20^{\text {th }}$ day), during the months of September through December, considering the soil types with water storage capacities of 20, 40 and $60 \mathrm{~mm}$ (Figure 2).

For these three soil types, there is a wide spatial variation for the joint planting, which evidences the variability of rainfall in the state during the period analyzed. Regardless of the soil type, the areas with lowest climatic risk occur in October and November. In the planting simulations in September and December the areas with medium and high climate risk increase, showing there is a climatic restriction caused by low rainfall.

Analysis of a single planting period for different soil types shows that at any time there is a positive relationship between increased water retention capacity and reduced planting risk, due to the increased water available from soils with higher clay contents (Figure 3). Considering the average of all the simulated sowing dates, the areas considered as having low climate risk are those with more presence of soils able to retain $60 \mathrm{~mm}$ (74.3\%), followed by soil with water storage of $40 \mathrm{~mm}$ (52.3\%) and $20 \mathrm{~mm}$ (7.28\%). These results are similar to those reported by Andrade Junior et al. (2007).

For soils with medium water retention $(40 \mathrm{~mm})$, over $50 \%$ of the area of the São Paulo state presents low risk for joint planting in the period from October through December, and there are practically no regions with high risk for soils of this type. In turn, for soils with high water storage capacity 


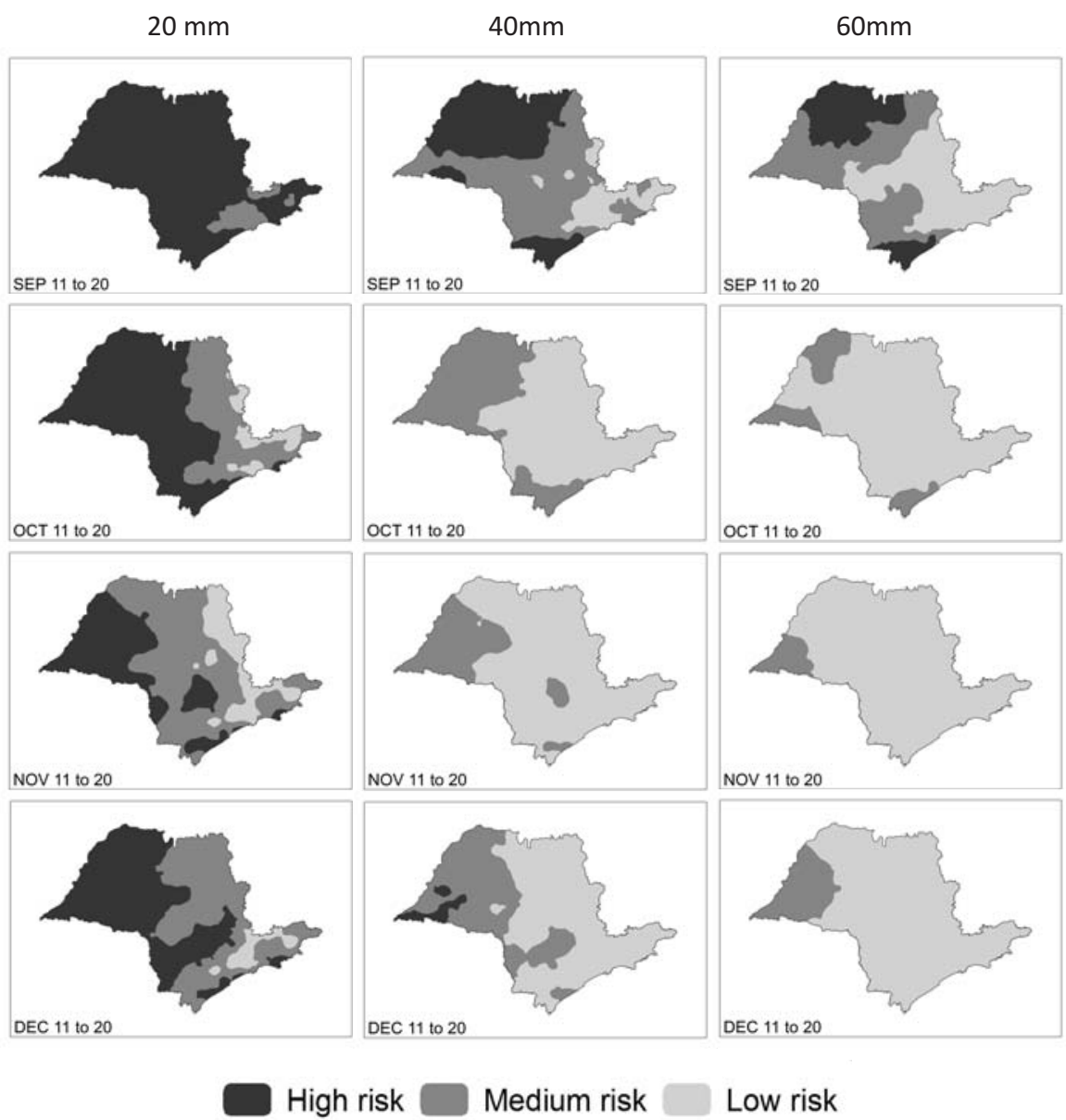

Figure 2 - Spatial distribution of climatic risks of joint planting of corn and palisade grass between September 11 and December 20 , considering soils with water storage capacities of 20, 40 and $60 \mathrm{~mm}$, for the state of São Paulo.
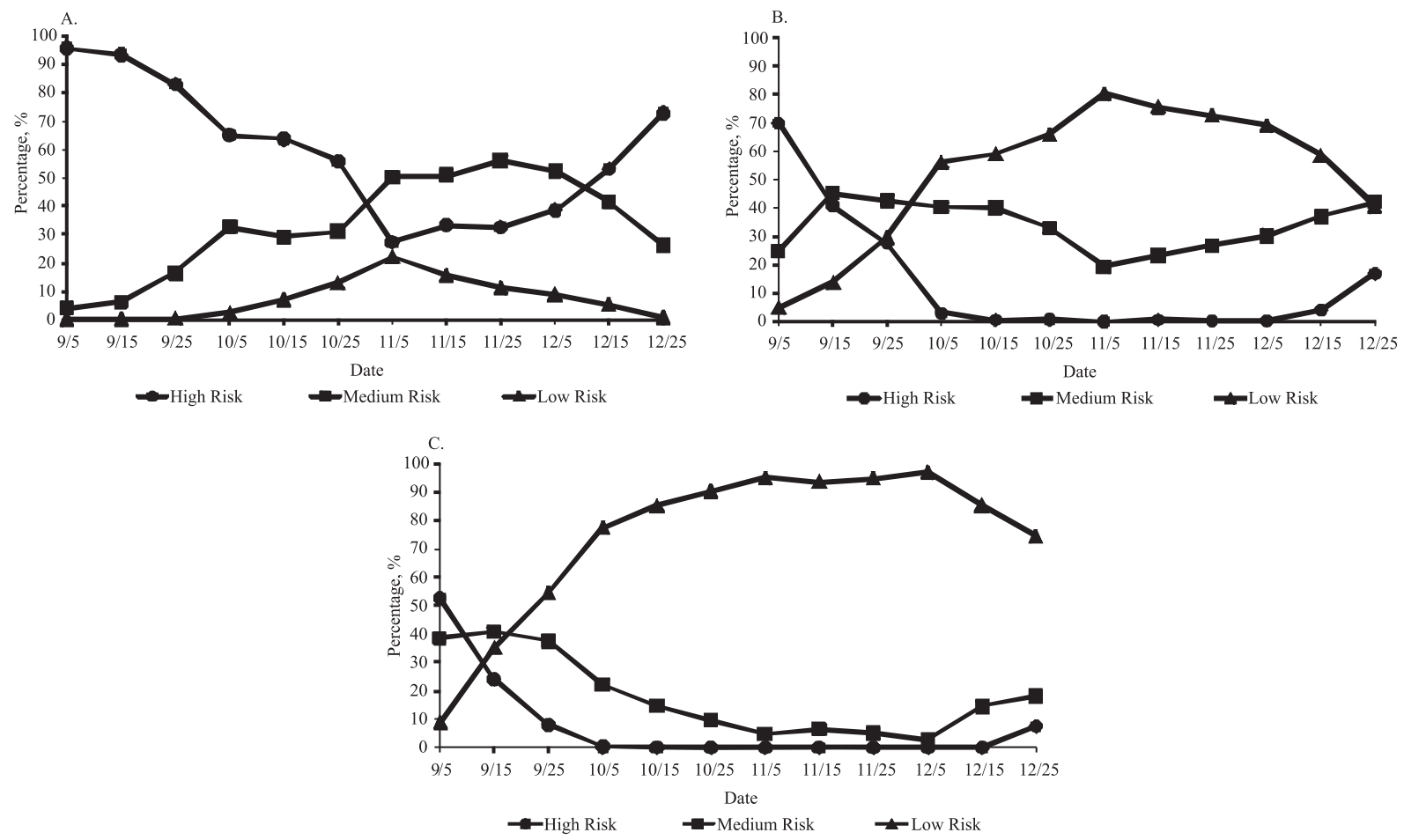

Figure 3 - Fraction of area (\%) and associated risk levels for joint planting of corn and palisade grass in the state of São Paulo from September through December, in soils with water storage capacities of 20 (A), 40 (B) and 60 (C) mm. 
(60 mm), over $70 \%$ of the state area shows low risk for joint sowing in the period from October through December.

The distribution of the percentages of high-risk areas in the state for the three soil types is associated with the rainfall levels in the state during the spring-summer. In September and October, the small volume of rain associated with the large annual variability causes risks mainly to the planting of pasture, while in December, the increase of risky areas is associated with the occurrence of dry spells, because of the effect of water deficiency on the flowering and grain-filling states of corn, impairing the yield of this crop (Brunini et al., 2001). The situation tends to invert when analyzing the percentages of low-risk areas.

The results found in this study show more restricted low-risk periods and areas than what was reported by Brunini et al. (2001) in a risk zoning study for corn alone in São Paulo. It must be considered that, with joint planting, the water demand, expressed by crops evapotranspiration, is higher because of the greater crop coefficient values used, as proposed by Silva et al. (2007).

In these two situations (analyses of the percentages of high- and low-risk areas), it is evident that the behavior of the percentage curves of the areas is influenced by the water storage capacity of the soil.

\section{Conclusions}

The state of São Paulo has areas of low climatic risk for crops of corn and palisade grass, with the variations imposed by the water availability level. For soils with low water retention capacity, there is restriction on sowing in most of the state in the months of September through December, while for soils with greater water storage capacity, the period with the lowest climate risk for these two crops occurs from October and November.

\section{References}

ASSOCIAÇÃO BRASILEIRA DAS INDÚSTRIAS EXPORTADORAS DE CARNE - ABIEC. Exportações de carne bovina do Brasil - Janeiro a December de 2009. Available at: <http://www.abiec.com.br/download/EXP\%20JAN-DEZ\%2009.pdf>. Accessed: Oct. 5, 2010.

ANDRADE JÚNIOR, A.S.; BARROS, A.H.C.; SILVA, C.O. et al. Zoneamento de risco climático para a cultura do feijão caupi no
Estado do Ceará. Revista Ciência Agronômica, v.38, n.1, p.109-117, 2007.

ARAUJO, L.C.; SANTOS, P.M.; MENDONÇA, F.C.; MOURÃO, G.B. Establishment of Brachiaria brizantha cv. Marandu, under levels of soil water availability in atages of growth of the plants. Revista Brasileira de Zootecnia, v.40, n.7, p.1405-1411, 2011 a.

ARAUJO, L.C.; SANTOS, P.M.; MENDONÇA, F.C.; LIMA, N.C.B.de. Development of maize and palisade grass plants cultivated in intercrop under water deficit. Revista Brasileira de Zootecnia, v.40, n.7, p.1397-1404, 2011b.

BARON, C.; PEREZ, P.; MARAUX, F. Sarrazon: Bilan hidrique apliqué au zonage. Montpellier: CIRAD, 1996. 26p.

BERGAMASCHI, H.; DALMAGO, G.A.; BERGONCI, J.I. et al. Distribuição hídrica no período crítico do milho e produção de grãos. Pesquisa Agropecuária Brasileira, v.39, n. 9, p.831-839, 2004.

BERGAMASCHI, H.; DALMAGO, G.A.; COMIRAN, F. et al. Déficit hídrico e produtividade na cultura do milho. Pesquisa Agropecuária Brasileira, v.41, n.2, p.243-249, 2006.

BRUNINI, O.; ZULLO JUNIOR, J.; PINTO, H.S. et al. Riscos climáticos para a cultura de milho no estado de São Paulo. Revista Brasileira de Agrometeorologia, v.9, n.3, p.519-526, 2001.

GUENNI, O.; MARIIN, D.; BARUCH, Z. Responses to drought of five Brachiaria species. I. Biomass production, leaf growth, root distribution, water use and forage quality. Plant and Soil, v.243, p.229-241, 2002.

MILES, J.W.; VALLE, C.B.; RAO, I.M. et al. Brachiaria grasses. In: MOSER, L.E.; BURSON, B.L.; SOLLENBERGER, L.E. (Eds.) Warm-season (C4) grasses. Madison: ASA/CSSA/SSSA, 2004. p.745-783.

INSTITUTO BRASILEIRO DE GEOGRAFIA E ESTATÍSTICA IBGE. Censo Agropecuário 2006. Rio de Janeiro: IBGE, 2009. Available at: <http://www.ibge.gov.br/home/estatistica/ economia/ agropecuaria/censoagro/brasil_2006/Brasil_censoagro 2006.pdf $>$. Accessed on: Oct. 5, 2010.

MILES, J.W.; VALLE, C.B.do; RAO, I.M. et al. Brachiaria grasses. In: MOSER, L.E.; BURSON, B.L.; SOLLENBERGER, L.E. (Eds.) Warm-season (C4) grasses. Madison: ASA/CSSA/SSSA, 2004. p. 745-783.

OLIVEIRA, I.P.; KLUTHCOUSKI, J.; YOKOYAMA, L.P. et al. Sistema Barreirão: recuperação/renovação de pastagens degradadas em consórcio com culturas anuais. Goiânia: Embrapa - CNPAF, 1996. 87p. (Embrapa CNPAF. Documentos, 64).

PEZZOPANE, J. R. M.; CASTRO, F.S.; PEZZOPANE, J.E.M. et al. Zoneamento de risco climático para a cultura do café Conilon no Estado do Espírito Santo. Revista Ciência Agronômica, v.41, p.341-348, 2010.

SANS, L.M.A.; ASSAD, E.D.; GUIMARAES, D.P. et al. Zoneamento de riscos climáticos para a cultura de milho na região centrooeste do Brasil e para o estado de Minas Gerais. Revista Brasileira de Agrometeorologia, v.9, n.3, p.527-535, 2001.

SILVA, F.A.M.; GUERRA. A.F.; ROCHA. O.C. et al. Consumo de água e coeficientes culturais do milho consorciado com Brachiaria brizantha. In: CONGRESSO BRASILEIRO DE AGrometeorologia, 15., 2007, Aracaju. Anais... Sete Lagoas: Sociedade Brasileira de Agrometeorologia, 2007. (CD-ROM). 